\title{
Religião e ética no cristianismo não religioso: Uma abordagem a partir de Gianni Vattimo
}

\author{
Religion and ethics in non-religious Christianism
}

\section{Paulo Sérgio Lopes Gonçalves*}

Pontifícia Universidade Católica de Campinas (PUC-Campinas), Campinas, SP, Brasil

\section{Resumo}

Objetiva-se neste artigo apresentar analiticamente a relação entre religião e ética na proposta do cristianismo não religioso de Gianni Vattimo. Justifica-se este objetivo o fato de que o filósofo italiano desenvolve a sua proposta assumindo a perspectiva niilista da ontologia hermenêutica, unindo a sentença nietzscheniana da morte de Deus e o projeto heideggeriano da superação da metafísica, para afirmar que o cristianismo é uma religião da encarnação do verbo, centrada na caridade, e, ao inserir-se no mundo, possui a missão de praticar a caridade, na condição de sua própria verdade. Para atingir este objetivo, será apresentado o estado da questão deste tema, afirmando as linhas fundamentais do cristianismo não religioso e a ética dele subjacente que se denominará analogamente ética cristã não religiosa, cujo fundamento material está

*PSLG: Doutor em Teologia, e-mail: paselogo@puc-campinas.edu.br 
situado em algumas obras e fontes desse filósofo italiano e de alguns outros pensadores que propiciam a análise do tema.

Palavras-chave: Cristianismo. Secularização. Pensamento fraco. Niilismo. Caridade.

\begin{abstract}
This paper aims at presenting analytically the relationship between religion and ethics in the proposal of Christianity not religious Gianni Vattimo. This objective justified the fact that the Italian philosopher develops your proposal, assuming the nihilistic perspective on hermeneutic ontology, uniting the nietzscheniana sentence of death of God and the heideggeriano of the project overcoming metaphysics, to assert that the Christianity is a religion of the incarnation of the word, centered in charity and to insert itself in the world, has the mission to practice charity, provided your own truth. To achieve this goal, I will present the State of the issue of this topic, assert the fundamental lines of Christianity is not religious and ethics underlying his will name similarly not religious Christian ethics, whose Foundation is material in some works and sources of this Italian philosopher and a few others that provide the analysis of the theme.
\end{abstract}

Keywords: Christianity. Secularization. Thoughtweak. Nihilism. Charity.

\title{
Introdução
}

O objetivo deste artigo é apresentar analiticamente a relação entre religião e ética na proposta do cristianismo não religioso de Gianni Vattimo. Para atingir este objetivo, será apresentado o estado da questão deste tema, afirmando-se as linhas fundamentais do cristianismo não religioso e a ética dele subjacente, que será denominada analogamente ética cristã não religiosa, cujo fundamento material se situa em algumas obras e fontes desse filósofo italiano e de alguns outros pensadores que propiciam a análise do tema.

Este objetivo é justificável pelo fato de que o filósofo italiano elabora a proposta supramencionada para propiciar a superação do absolutismo 
da instituição religiosa cristã, presente em seus dogmas, em suas prescrições morais e em suas regras disciplinares. Esta tese se fundamenta na teoria de que a secularização é a outra face do cristianismo, emergente a partir da relação desse mesmo cristianismo com o mundo moderno. Então, a secularização não é um fenômeno externo e de mera oposição ao cristianismo, mas originariamente intrínseca à própria dinâmica de inserção cristã no mundo. Neste sentido, a sentença nietzscheniana da morte de Deus, e a afirmação heideggeriana acerca da superação da metafísica, tornaram-se elementos fundamentais para indicar a tese do autor e sedimentar o que denominou cristianismo não religioso, na perspectiva de sua filosofia pós-moderna.

Essa filosofia está amparada na própria biografia de Gianni Vattimo, que nasceu em 1936, na Itália, doutorou-se em Filosofia na Universidade de Turim e especializou-se em Heidelberg, tendo sido aluno de Karl Löwith e Hans-Georg Gadamer, de quem herdou a esteira hermenêutica, através da qual aprofundou Nietzsche e Heidegger. Seu interesse pela filosofia decorre de sua militância cristã juvenil, tendo participado de um cristianismo católico de assiduidade às celebrações da eucaristia e de engajamento social, motivado por um contexto em que o tomismo retomado por Leão XIII, em sua carta encíclica AeterniPatris (1879), foi difundido na teologia fundamental de Pierre Rousselout e Joseph Maréchal (GONÇALVES, 2011), no personalismo de Emmanuel Mounier e, principalmente, no humanismo integral de Jacques Maritain (1936), possibilitando uma neocristandade em que os cristãos eram interpelados ao engajamento histórico-social para fundar partidos políticos, sindicatos e associações de caráter cristão-católico (LIMA VAZ, 2002, p. 239-267).

Esta fé cristã militante possibilitou que Vattimo visualizasse nas filosofias de Nietzsche e de Heidegger o caminho contundente para a sua atividade filosófica e, consequentemente para a aventura de constituição de seu pensamento. Conforme o filósofo italiano, essas filosofias possuem raízes judaico-cristãs, especialmente no que se refere aos conceitos metafísicos de Deus, homem e mundo. As respectivas teses desses filósofos possuem consonância com o substrato religioso cristão, seja para criticá-lo seja para redimensioná-lo hermeneuticamente. Por isso, o próprio Vattimo se autocaracteriza como um cristão niilista, imbuído de uma história que o marca 
como cristão católico praticante e como um filósofo com as evidentes marcas de Nietzsche e Heidegger, críticos do cristianismo fundamentado na metafísica a ser destruída (VATTIMO, 1998, p. 23-28).

Amparado em Nietzsche e Heidegger, em sua obra La fine dela Modernitàde 1985 (2002), Vattimo se apropria do conceito de Pósmodernidade desenvolvido por François Lyotard (1993), em que objetivou "esclarecer a relação que liga as conclusões da reflexão de Nietzsche e de Heidegger, a que constantemente se faz referência, com os discursos mais recentes, sobre o fim da época moderna e a pós-modernidade" (VATTIMO, 2002, p. V). Para atender a esse objetivo, o autor apresenta o niilismo como destino, a crise do humanismo, analisa a arte como núcleo temático da pós-modernidade, afirma o fim da Modernidade e apresenta, mediante sua ontologia hermenêutica niilista, a verdade, a relação entre hermenêutica e antropologia na análise da cultura e, principalmente, a articulação entre niilismo e pós-modernidade na filosofia (VATTIMO, 2002, p. 109-190). O autor conceitua, então, a pós-modernidade como paradoxo marcado pela simultânea descontinuidade e continuidade da modernidade. Isso significa que as teses fundamentais da modernidade acerca da autonomia do homem e do advento da ciência moderna, concentrada na concepção de experiência como empiria e em seu caráter messiânico, passaram a ter consistência relativa com o advento do niilismo nietzscheniano e da ontologia hermenêutica heideggeriana. De um lado, foi trazida à tona a necessidade da interpretação das sentenças e a dialética entre desconstrução e reconstrução de valores. De outro, afirmou-se ter a metafísica se esquecido do ser e privilegiado o ente, principalmente o ente supremo, apontando a necessidade de sua ultrapassagem por uma ontologia fundamental em perspectiva hermenêutica. Deste modo, não se pode pensar a verdade como um conjunto de proposições objetivas e irremovíveis, tornadas absolutas em uma forma linguística determinada ou ainda pensar em fundamentos sólidos para a afirmação de prescrições morais e dogmáticas sobre o homem e o mundo (VATTIMO, 2016, p. 19-30).

Vattimo adere à ideia nietzscheniana de uma "filosofia da manhã, que é justamente o pensamento não mais orientado com base na origem ou no fundamento, mas na proximidade" (VATTIMO, 2002, p. 176). Essa filosofia da manhã está marcada por um eterno retorno do igual, que 
possibilita pensar a errância da metafísica não para dissipar os erros, mas para "vê-los como a própria fonte de riqueza que nos constitui e que dá interesse, cor, ser, ao mundo" (VATTIMO, 2002, p. 176). Isso remete ao que Heidegger denominou Verwindgung, cujo termo é compreendido como convalescença, propiciando visualizar os vestígios da metafísica, uma vez que esta é uma "cadeia de montanhas irremovíveis" (VON HERMANN, 2004, p. 14). No entanto, segundo a perspectiva heideggeriana, por ter se esquecido do ser e privilegiado o ente, especialmente o ente supremo, as proposições metafísicas não mais alcançam o advento do ser ao homem, em especial na relação entre mundo e terra, em que se apresenta a técnica - Ge-Stell. Trata-se da Ereignis - traduzida por acontecimentoapropriação ou como evento - em que o ser se dá ao homem na forma de destino — Geschick - e transmissão - Überlieferung — evidenciando, deste modo, um caráter epocal do ser (VATTIMO, 2002, p. 168-182).

Com este posicionamento, Vattimo assume uma filosofia pós-moderna como pensamento da fruição, da contaminação e da técnica (VATTIMO, 2002, p. 183-190), em que são apresentadas como características a flexibilidade, a nomadologia, a transversalidade, a fragmentação e a relação entre unidade e multiplicidade ou, ainda, uma filosofia da diferença (OLIVEIRA, 2003, p. 43-52). A esta forma de pensar ou de filosofar, Vattimo denomina pensamento débil ou ontologia fraca, através do qual se tem um novo começo do pensar, em uma nova época do ser (VATTIMO, 2002, p. 190). A compreensão da epocalidade do ser remete a pensar a verdade não mais em sua objetividade metafísica, tal como se configurou em formulações dogmáticas, prescrições morais e teorias científicas modernas, mas como aletheia em sua condição de lichtung - clareira - e abertura (PEREZ, 2012, p. 188-192).

\section{0 retorno da religião ou a religião do retorno?}

Com a sua filosofia pós-moderna de centralidade no pensamento débil, Vattimo analisou filosoficamente a religião ao organizar "O Seminário de Capri”, em 1994, conjuntamente com Jacques Derrida, contando com a presença reflexiva de Hans-Georg Gadamer e outros filósofos italianos, e ao 
escrever outras obras, em especial, Credere di credere em 1998 (1999) e Dopo La cristinità (2001). Em todos esses escritos, a motivação fundamental de Vattimo para pensar a religião é o próprio clima pós-moderno do substrato religioso, em que a religião não é monopólio das instituições religiosas, está imbuída de pluralidade e salvaguardada juridicamente no âmbito da liberdade religiosa (DERRIDA; VATTIMO, 2000).

A interpretação da sentença nietzscheniana da morte de Deus, presente no fragmento 125 de A Gaia Ciência é, para Vattimo, o desafio de pensar que Deus morreu. Por isso, une ao trabalho da interpretação dessa sentença a afirmação heideggeriana do fim ou dissolução da metafísica. Aparentemente, essas afirmações apresentavam a possibilidade de pensar a negação substancial de Deus, o fim da religião e a eliminação da metafísica.No entanto, essa sentença se relaciona à morte do Deus criador e todo-poderoso da metafísica e da ruptura dos paradigmas metafísicos que amparavam as concepções de homem e mundo. Coloca-se fim ao Deus imutável, ao mundo predestinado, ao homem fundamentado no Deus metafísico, e instaura-se o niilismo em que se dá início a uma nova valoração da vida humana e cósmica (ALMEIDA, 2012, p. 63-76). Tem-se o fim dos fundamentos e das metanarrativas, e inicia-se a era das pequenas narrativas, das fábulas e outros gêneros literários, imbuídos de linguagem metafórica (LYOTARD, 1993). O fundamento se torna desfundamento ou sem fundamento - o Abgrund na linguagem heideggeriana - que implica que o fundamento é abissal (HEIDEGGER, 1976b), requer novas interpretações, percursos hermenêuticos novos nos livros, e inclusão dos símbolos e da ação no próprio processo hermenêutico (RICOEUR, 2011).

A promessa positivista de que a ciência seria o último estágio da humanidade, eliminando tanto a religião quanto a filosofia não teve êxito. A morte de Deus não significa ateísmo em seu sentido estrito, nem desaparecimento pleno da religião, mas a necessidade de que à questão de Deus se requeira uma nova atenção ontológico-hermenêutica e de que a religião seja vista em uma nova realidade, marcada pelo pluralismo e pelo sincretismo. Assim sendo, a religião não desaparece da vida e retorna ao cenário histórico sem a conotação dogmática, moralista e jurídica de antes, mantendo-se em seu tema propriamente religioso: a fé. No entanto, retornar à fé tematicamente não é uma redução da fé, porém 
tomá-la como sentido da própria existência do homem, principalmente na relação estabelecida com Deus. O homem tomapara si não apenas a conformação de sua finitude e de sua falibilidade, mas também a certeza de sua transcendência (VATTIMO, 1998, p. 7-16).

O retorno à religião como tematização da fé, objetivando visualizar o sentido da existência, remete à compreensão da secularização, cuja aparição apontava inicialmente para uma situação de contraposição à religião. No entanto, a compreensão de Vattimo remete à posição de que a secularização se relaciona ao cristianismo, constituindo-se em um movimento decorrente da ação do cristianismo em sua relação com o mundo, efetuada de modo análogo à encarnação do Verbo de Deus na história humana. A encarnação - Kénosis - do Verbo de Deus na história aponta para um acontecimento fundamental: a revelação do Filho de Deus para trazer a salvação para os povos. Sua demanda implicou em sua inserção em uma cultura, em um tempo histórico determinado, e em apontar caminhos éticos e morais consoantes à salvação cristã. Não obstante que a secularização explicite a pluralidade de religiões, especialmente as monoteístas - com difusão maior do islamismo - e as brâmanes, principalmente o budismo e o hinduísmo, denota também o engajamento do cristianismo no mundo, incidindo na vida dos povos em termos políticos e morais. Os valores cristãos, que já haviam sido incorporados à cultura ocidental, passam a ser redimensionados hermeneuticamente como consequência do niilismo contemporâneo (VATTIMO, 2004, p. 75-88).

Retornando à ideia de pensamento débil ou ontologia fraca, Vattimo apoia-se nas teorias sobre sacrifícios religiosos de René Girard (1990; 2004), para afirmar o cristianismo como via de secularização (VATTIMO, 1998, p. 29-44), em que a tradição judaico-cristã adere ao sacrifício cruento e violento para exprimir a expiação dos pecados e a aliança com Deus. Assim sendo, não são raros os cultos sacrificais encontrados no antigo testamento que reforçam a aliança entre Deus e seu povo: holocaustos ( $\operatorname{Lv} 1)$, sacrifícios de comunhão ( $\operatorname{Lv} 3)$, sacrifícios de expiação ( $\operatorname{Lv} 4)$, sacrifícios de reparação ( $\operatorname{Lv} 7,1-6)$, sacrifícios de direitos do sacerdote (Lv 7, 7-10), sacrifícios doxológicos e votivos ( $\operatorname{Lv} 7,11-17)$, sacrifícios da aliança ( $\mathrm{Gn} 15)$. No novo testamento, o sacrifício continua cruento, 
mas não mais constituído de dois sujeitos — os animais vitimários e os sacerdotes mediadores, para que fossem expressas a relação de Javé com Israel e a consolidação da aliança na celebração cultual. Afinal, há um único sujeito, Jesus Cristo ( $\mathrm{Hb} 10$ ), que sintetiza em si, a condição de vítima e de mediador. Nesta perspectiva, merece destaque a carta aos hebreus, que, contextualizada em uma crise explícita referente ao templo do judaísmo, evidencia o caráter redentor do sacrifício de Cristo, por se tratar de um sacrifício amoroso, em que mediador e mediação se identificam para que seja efetiva a redenção e a salvação (PIXLEY, 1991). $\mathrm{Na}$ concepção girardiana, a sociedade humana possui um potente impulso mimético, que é também a raiz da crise ocorrida quando, na necessidade de imitar o outro, emerge a vontade de se apropriar das coisas do outro, estabelecendo uma guerra de todos contra todos. Dessa guerra resulta a necessidade de ter um bode expiatório que é sacrificado para selar a paz entre os que guerreiam. Esse bode expiatório assume atributos sagrados, conferindo ao seu sacrifício vitimário uma conotação soteriológica. Eis aqui um paradoxo que o próprio Girard assume enquanto é um fenômeno invisível, "cuja elucidação é humanamente impossível” (GIRARD, 2010, p. 108). Ao assumir o sacrifício de Cristo como produto de um mecanismo vitimário fundacional, o cristianismo se une às demais religiões e, ao mesmo tempo, torna-se incomparável a elas. De um lado, essa singularidade se deve ao próprio processo do mecanismo vitimário, em que o sacrifício é consenso entre perseguidos e perseguidores, e, de outro lado, é sacrifício do Deus que se fez homem. Aqui reside o elemento crucial da apropriação de Girard por parte de Vattimo: a encarnação do Verbo de Deus propicia o sacrifício redentor. Sem a encarnação seria impossível conferir ao sacrifício conotação soteriológica, cuja consolidação está na ressurreição de Jesus. Mas por que o sacrifício é coroado com a ressurreição? Porque o sacrifício de Cristo possui a marca do amor que transcende a "violência do sagrado e deve penetrar, enfim, no obscuro reino do homem; ele deve triunfar sobre todos os obstáculos que nós pomos no caminho da nossa própria salvação" (GIRARD, 2013, p. 118).

Com a teoria girardiana, Vattimo complementa a sua tese de identificação entre a sentença nietzscheniana da morte de Deus e a afirmação heideggeriana do fim da metafísica, cuja aplicação ao 
cristianismo possibilita dar centralidade à caridade, em sua inserção no mundo. Neste sentido, o cristianismo não encontra na secularização a sua inimiga a ser combatida, mas a outra face de sua identidade, desenvolvida ao encarnar-se no mundo, ultrapassando a fronteira institucional religiosa e se instaurando no mundo pós-moderno a partir da prática da caridade. Deste modo, o cristianismo se caracteriza como um cristianismo não religioso (ROTTERDAN; SENRA, 2015, p. 106-115).

\section{0 cristianismo não religioso: faktische lebenserfahrung e Ereignis}

A dissolução da metafísica afirmada por Heidegger é fundamental para a tese vattimiana do cristianismo não religioso por se tratar de compreensão ontológico-hermenêutica da Ereignis, em que o ser se dá ou advém ao homem. Essa compreensão, porém, requer a apropriação da faktische Lebenser fahrung que Heidegger afirmara, no início da década de 1920, para analisar fenomenologicamente a experiência religiosa de algumas cartas paulinas, de Santo Agostinho no livro X das Confissões e da mística medieval (HEIDEGGER, 1995). A atenção de Vattimo se centra na análise das duas cartas aos tessalonicenses e na carta aos gálatas. Com isso, apresenta a concentração de Heidegger na faticidade da vida, que incide na preocupação paulina em como viver a fé cristã e a esperança escatológica com centralidade na caridade. Deste modo, a fé não se reduz ao raciocínio ou ao sentimento isento de vitalidade fática, mas se efetiva em experiência de vida fática, identificada como próprio existir humano (GONÇALVES, 2012). A religião é, então, a experiência de fé vivida no interior da própria vida do homem, enquanto é experiência fática. Essa experiência remete a Ereignis, cuja compreensão de Heidegger na carta sobre o humanismo - Briefen über den Humanismus - remete ao dar-se do ser ao homem. O cume desse movimento é a linguagem, concebida como a casa do ser e cuidada pelo homem, concebido como Pastor do ser — Hirt dês Seins - (HEIDEGGER, 1976a, p. 331). Ao advir a esse Pastor, o ser assume um caráter epocal, propiciando que o cristianismo seja uma religião contemporânea da época histórica em que se situa. Essa religião se efetiva na vida mesma do cristão, marcada por sua condição histórica e 
pela dinâmica da fé, que conduz a esperar escatologicamente pelo retorno do Senhor, na caridade que permanece para sempre (VATTIMO, 2004, p. 151-167). Mas como é possível esperar na caridade à luz da fé?

Na concepção vattimiana, é impossível esperar na caridade pela mediação da metafísica que possibilitou o dogmatismo da fé, da moral e de prescrições jurídicas em relação ao comportamento, aos sacramentos e à liturgia. Urge a necessidade hermenêutica de reinterpretar a Escritura, a dogmática, aética e a moral cristã. Esse investimento hermenêutico vattimianona Escritura possibilita remeter a Gioacchino de Fiore, um monge beneditino medieval que visualizou três eras da humanidade: a do Pai — do antigo testamento - , a do Filho - novo testamento - e a do Espírito - a era da Igreja ou da humanidade moderna. A concepção gioacchiniana acerca do Espírito - ruah, pneuma, spiritus - e sua ação na história indica a vitalidade da revelação cristã presente na Escritura e na história em geral. Esta revitalização da Escritura, mediante a atuação do Espírito, já se apresentava em alguns padres dos primeiros séculos da Igreja e incidiu na exegese medieval, possibilitando a formulação dos quatro sentidos da Escritura: literal, moral, alegórico e anagógico (DE LUBAC, 1966). O conjunto desses quatro sentidos é denominado doutrina da inteligência espiritual da Escritura, da qual decorre a necessidade de reinterpretar a Escritura à luz do Espírito que vitaliza a letra do livro sagrado. Disso decorre a "capacidade de entender os eventos narrados pela Bíblia antes e, talvez, mais fundamentalmente, como 'figuras' de outros eventos históricos, do que como parábolas voltadas para a edificação dos fiéis" (VATTIMO, 2004, p. 41).

A inteligência espiritual da Escritura possibilita que o texto sagrado se torne constantemente atual ou contemporâneo das diversas épocas históricas. Isso significa que a espiritualidade gioacchiniana propiciou compreender que as três eras ou idades, a do Pai, a do Filho e a do Espírito, são respectivamente as eras da lei, da graça e de um estado de graça mais perfeito, ou, ainda, as eras do flagelo, da ação e da contemplação. Essas eras transcorreram na escravidão, na servidão filial e na insígnia da liberdade. São todas eras históricas, cuja possibilidade de liberdade é ação do Espírito. A essa era de liberdade denomina-se um novo sinal dos tempos - categoria utilizada por Marie-Dominique Chenu (1937) para 
designar o modo como Deus se revela na história e como a história se torna campo da revelação divina - em que a metafísica começa a passar por um processo de dissolução e se inicia um novo início, de descoberta do ser como acontecimento-apropriação - Ereignis - e como destino Geschick - de enfraquecimento (VATTIMO, 2004, p. 37-54).

Ao invocar Gioacchino de Fiore para apresentar a era da liberdade trazida pelo Espírito, Vattimo penetra o contexto da secularização, apresentando-a como um estado que requer uma nova apresentação da religião cristã, situada no contexto pós-moderno, a ser pensada, então, na situação de pluralismo, tanto em termos culturais quanto religiosos, e ecumênico, exigindo do cristianismo uma redescoberta de si e do próprio Deus, cuja fé professa. Neste sentido, invoca-se também não só o grande trabalho desenvolvido por Henri De Lubac ao recriar a exegese católica e ao buscar desenvolver sua teologia da história em diálogo com as situações de ateísmo e de pluralidade das religiões (DE LUBAC, 1978), mas também a perspectiva de Karl Barth ao afirmar o Deus totalmente Outro (BARTH, 2004) e a visão de Dietrich Bonhoeffer ao assumir positivamente a secularização, quando propõe uma ética cristã fundamentada na concepção de um Deus que se apresenta compassivamente nos campos de concentração (BONHOEFFER, 1969).

Essa redescoberta de si e de Deus por parte do cristianismo aponta para a articulação entre Espírito e kénosis do Verbo, que encontra na inserção do cristianismo no mundo sua analogia histórica. Deste modo, a era do Espírito é a apresentação do cumprimento da história da salvação, interpretada como a morte de Deus, a dissolução da metafísica e a manifestação de um novo cristianismo, concebido como não religioso. Esse cristianismo interpreta a história da salvação como efetivamente histórica, como um acontecimentoapropriação do ser que se dá ao homem, cuja história exigirá um processo, conforme a analogia com o entendimento bultmanniano de demitização da fé (BULTMANN, 2001) ou ainda de reinterpretação da fé em consonância com os sinais dos tempos. O programa bultmanniano de demitização implica avaliar e reinterpretar a moral cristã, principalmente no âmbito da sexualidade, em que novas situações de gênero e questões de bioética estão em cena. Também vale recordar que o processo de demitização remete a uma hermenêutica dos dogmas, contextualizando-os histórica e teologicamente, 
e explicitando a historicidade contemporânea de sua mensagem (VATTIMO, 1998, p. 49-58).

Dessa hermenêutica soteriológica emergirá uma nova concepção de Deus - só há um deus que salva (HEIDEGGER, 1966) - que possui a estética como canal imprescindível de representação, denominado "Deus ornamento" (VATTIMO, 2004, p. 55). Essa representação implica superar a ideia moderna de progresso, que aponta para um horizonte de perfeição do homem e do mundo, muito própria de uma teologia da criação que fundamenta sistemas totalitários e tipicamente eurocêntricos. Com uma nova inteligência espiritual da Escritura e com uma visão unitária da história, superando o dualismo entre história sagrada e profana, há de se concentrar na caridade e implantar um processo de tolerância, de redução da violência e de diálogo com outras religiões e com pessoas que vivem em outras situações históricas e não explicitamente religiosas (VATTIMO, 2004, p. 55-72). A estetização de Deus aqui deve trazer uma nova escatologia, não mais marcada pela passagem do homem ou sua alma ao purgatório constituído de castigos duros ou ao inferno de condenação eterna e de castigos horríveis e permanentes, mas de "fruição perfeita dos significados e das formas espirituais que a história da humanidade produziu e que constituem o reino da imortalidade" (VATTIMO, 2004, p. 72).

O cristianismo não religioso apresenta-se como uma religião transfigurada, uma religião que retorna apresentando a vitória de um Deus que propicia o renascimento dos deuses. Neste sentido, a história do ocidente, que se identifica tanto com a história do cristianismo, é também reconfigurada e necessitada de superação do eurocentrismo e do imperialismo étnico e político, que tem possibilitado diversas formas de fundamentalismos, que acabam por impulsionar a violência e o terror. Concentrando-se na inteligência espiritual da Escritura e na hermenêutica da dogmática e da moral, o cristianismo não religioso vai ater-se às propostas comunitárias que explicitam um retorno às fontes cristãs, visando superar a identificação com fundamentalismo religioso e relativismos. Além disso, há de se concentrar na caridade, para que a perspectiva comunitária seja imbuída historicamente e com caráter de contemporaneidade, demonstrando sapiência na leitura dos sinais dos tempos (VATTIMO, 2004, p. 89-116). 


\section{Ética cristã não religiosa}

Conforme o exposto, o cristianismo não religioso proposto por Gianni Vattimo propicia uma ética que se pode denominar analogamente ética cristã não religiosa, pois sua formulação se ampara na encarnação ou kénosis do Verbo na história, visando se concentrar na caridade. Por isso, utiliza-se da hermenêutica em sua condição de elemento pertinente e fundamental à efetividade da pós-modernidade, trazendo à tona o fim da metafísica concebida em sua objetivação conceitual, seja na própria filosofia seja na ciência moderna.

Ao considerar que o cristianismo não religioso se concentra na prática da caridade, cuja possibilidade está no desenvolvimento da liberdade, aponta-se para um novo modo de conceber a ética ou de uma nova postura de ação ética. Neste sentido, Vattimo considera que se vive atualmente uma crise ou descrédito da ética de cunho normativo, que se fundamenta em princípios metafísicos e de pretensão à universalidade, já que a condição pós-moderna evoca a contextualização, a parte, o fragmento, que constitui um todo, o pluralismo cultural, a flexibilidade, a transversalidade e a epocalidade, de modo a indicar a superação da ética essencialista,mediante a dissolução dos primeiros princípios e a "afirmação de uma pluralidade não unificável” (VATTIMO, 2016, p. 96). Em termos interrogativos, como desenvolver "um discurso ético - princípios dos quais derivam máximas de ação, recomendações de comportamento, hierarquia de valores - sobre a base de uma proveniência ou colocação epocal, caracterizada como dissolução dos fundamentos?" (VATTIMO, 2016, p. 96). Trata-se de elaborar um processo de reconstrução da ética em perspectiva pós-metafísica, em que se acentuam a condição histórica do homem e a sua pertença a uma comunidade de pessoas. Deste modo, os horizontes podem ser ampliados para que a ética tenha como referência a proveniência, caracterizada como dissolução dos princípios universais e últimos, e elemento que propicia a responsabilidade compartilhada. A proveniência se constitui por componentes diversos e múltiplos que superam os denominados fundamentos últimos, caracterizando-se como niilismo, mediante o qual se comporta criticamente "em relação a tudo 
aquilo que pretende apresentar-se como princípio último e universal" (VATTIMO, 2016, p. 97).

A ética oriunda da proveniência denota o reconhecimento da condição histórica e da finitude do homem, de modo a se apresentar em um processo de simultaneidade entre desconstrução e reconstrução dos valores que permeiam as sociedades e as atitudes humanas. Por isso, tornase pertinente e relevante que, na elaboração desta ética, conste a escuta da herança que não conduz apenas à "desvalorização de todos os valores, mas também à retomada e persecução de determinados conteúdos herdados" (VATTIMO, 2016, p. 101). A retomada dessa herança é feita com isenção da violência metafísica objetivista, que impõe padrões de comportamento e visões dogmático-doutrinárias. Para isso, torna-se necessário que essa ética seja elaborada mediante um processo que considere a alteridade, tão própria do pluralismo cultural, social e religioso, e reconheça a finitude, o limite humano e a situação hermenêutica de compartilhamento com outrem, em que cada pessoa se encontra. "O respeito ao outro é sobretudo o reconhecimento da finitude que nos caracteriza a ambos e que exclui qualquer superação definitiva da opacidade que cada qual carrega consigo" (VATTIMO, 2016, p. 102).

Utilizando-se da hermenêutica gadameriana (GADAMER, 2003), também interpretada por Luigi Pareyson (1998), Vattimo evoca a construção desta ética da proveniência, que pode ser denominada também ética cristã não religiosa, centrada na caridade, mediante um processo hermenêutico de fusão de horizontes, em que as pessoas se identificam como membros de uma comunidade, posicionam-se circularmente, para olharem a vida a partir de seu horizonte, levadas a olhar o horizonte do outro, realizando um processo dialógico. Por diálogo - dien ou lúmen conjugado a logos - , entende-se um processo comunicativo, em que os protagonistas têm condições para falar, escutar e entrar em consenso. Mediante o diálogo, a liberdade dos sujeitos é manifestada de modo situado, porque não há liberdade sem a emergência da alteridade que indica o outro, merecedor de respeito e imbuído de responsabilidade.

Esta ética cristã não religiosa, movida pela hermenêutica e pelo próprio processo de demitização,é também crítica em relação à ética metafísica, incidindo em temas referentes ao gênero, à sexualidade, às 
questões clínicas de origem - técnicas artificiais de fecundação, aborto - desenvolvimento - cuidados efetivos e paliativos, políticas sociais de saúde, nutrição — e final da vida — eutanásia —, à configuração econômica e política da sociedade. Em termos interrogativos: porque se deveria preservar a lei natural, quando o próprio conceito de natureza já é assaz questionado filosoficamente? Por que recriminar a homossexualidade, como se ela fosse mera manifestação de vontade ou escolha sexual? Por que o controle de natalidade deve ser feito apenas pelo que se denomina lei natural? Por que as pessoas não podem ser livres para escolher pela eutanásia, quando estão em situação de sofrimento oriundo de doenças incuráveis? Não estaria em jogo a liberdade, que é própria do homem, para ser exercida com responsabilidade compreendida à luz da alteridade? No âmbito das questões sociais, como efetivar a justiça à luz de um paradigma que suprima a primazia do interesse próprio, mas que também não incida em uma ditadura do Estado coletivista? Como superar o imperialismo político, as formulações etnocêntricas e sistemas econômicos que produzem enormes desigualdades sociais? Haveria modelo único para efetivar tal superação? (VATTIMO, 1998, p. 70-75).

Pensar essas questões exige olhar para o significado do pensar ontológico-hermenêutico, cuja verdade jamais se encerra em formulações dogmáticas, prescrições morais e normas disciplinares absolutizadas. A verdade é aletheia, compreendida como abertura que clarifica e fruto do diálogo à medida que possibilita ampliá-lo para atingir o consenso que seja resultado do bom senso dos sujeitos que efetivam esse processo comunicativo. Neste sentido, a ética cristã não religiosa, seguindo a esteira de Jürgen Habermas (2007), em sua filosofia do agir comunicativo, compreende a necessidade de encontrar canais de comunicação entre as pessoas em sua sociedade, cujo valor democrático está em possibilitar espaços de diálogo que sejam plausíveis à edificação da democracia, em que todos os membros de uma sociedade são sujeitos ativos do rumo dessa mesma sociedade. Esta comunicação dialógica que possibilita a democracia tem como luz a caridade, que transforma as pessoas e as suas relações sociais, possibilitando a edificação da justiça e da paz (VATTIMO, 2016, p. 19-57).

O pensar da ética cristã não religiosa diz adeus à verdade da metafísica objetivista e se constitui relativo ao ser que se situa epocalmente e possui 
historicidade, emergindo como resultado de um processo hermenêutico acerca da verdade, concebida como "projetalidade aberta que subtrai todo caráter retrospectivo à filosofia” (VATTIMO, 2016, p. 137).

Neste sentido, Vattimo entende que a verdade só pode ser apresentada quando há caridade - solidariedade na expressão de Rorty, com quem o filósofo italiano realizou intenso diálogo (ZABALA, 2005) —, concebida no que beneficia o homem em seu caráter pessoal e social. A identificação entre verdade e caridade supera toda expressão que se fixa em si mesma e que se impõe violentamente às pessoas, e torna absolutas as instituições e suas respectivas formulações. "A única verdade que a Escritura nos revela, que, ao longo do tempo, não pode sofrer nenhuma demitização - já que não é enunciado experimental, lógico, metafísico, mas é um apelo prático - é a verdade do amor, da caritas (VATTIMO, 2005, p. 53)".

Concentrada na caridade, a ética cristã não religiosa se consolida questionando os universalismos, os naturalismos e os evolucionismos, próprios da metafísica, compreendendo-os como produtores de violência e de tolhimento da liberdade, mediante formulações morais, disciplinares, jurídicas e dogmáticas. Consolida-se também por meio da hermenêutica que a coloca em constante movimento de interpretação dos eventos históricos, realçando a salvação cristã na vigilância, de modo a trazer à tona a verdade através da operação da caridade na história (VATTIMO, 2016, p. 129-138). Desta forma, essa ética denota

o esforço da filosofia em superar o objetivismo metafísico com a busca de uma visão do cristianismo que, quer no plano dos dogmas quer no plano da ética, seja, finalmente, capaz de pensar o próprio sentido ecumênico também, e acima de tudo, como escuta da nova época — pós-moderna do ser (VATTIMO, 2004, p. 167).

\section{Questões disputadas: metafísica e institucionalização da ética}

A ética subjacente no cristianismo não religioso vattimiano é fundamentalmente crítica às formulações metafísicas objetivistas e absolutistas, mostrando-se original ao caracterizar-se como hermenêutica cristã niilista, cuja referência articuladora entre cristianismo e niilismo é a 
própria biografia do filósofo italiano. Disso resulta então o seu cristianismo não religioso que, por concentrar-se na articulação entre ontologia hermenêutica heideggeriana e niilismo nietzscheniano, questiona e refuta a metafísica em sua formulação objetivista, em que as expressões se fecham e não se abrem às novas possibilidades de interpretação. Partindo da interpretação, inclusive da proposição nietzscheniana de que tudo é interpretação, Vattimo compreende ser a história da salvação uma história a ser interpretada (VATTIMO, 2005, p. 47) conforme a epocalidade do ser, em seu modo de acontecer e ser apropriado pelo homem situado em sua história. O processo hermenêutico é marcado por uma concepção de verdade como abertura, que exige um processo dialógico, fundado na concepção gadameriana de fusão de horizontes. Com isso, os dilemas éticos referentes à sexualidade, ao gênero, à origem, desenvolvimento e final de vida, e à sociedade são concebidos a partir dessa hermenêutica niilista, em que se efetiva um processo que o autor denomina dialógico. Deste modo, o filósofo italiano, ciente de sua situação hermenêutica, visualiza a postura das instituições religiosas, especialmente da Igreja católica em relação a esses temas como dogmática, legalista e moralista, quando assim se procede.

Não obstante que se possa debater diversos pontos da ética cristã não religiosa, considera-se dois pontos fundamentais dessa ética no ato mesmo de filosofar e na tradição filosófica: a metafísica e a institucionalização da ética cristã.

A metafísica não está superada ou destruída em seu sentido literal, mas redimensionada na perspectiva da ontologia hermenêutica - como projetou Heidegger - ou na perspectiva de uma metafísica de caráter histórico e fenomenológico, também com a pretensão de ser histórica e filosoficamente atual.Neste sentido, a metafísica é um discurso filosófico que, em sua formulação originária, é constituída de duas palavras metáe phisica - corresponde paradoxalmente à relação com a física e com o que vem depois dela. Deste modo, a metafísica apresenta de um lado, a dependência da física e de outro, a sua distância e superação. Por constituirse desse caráter paradoxal, a metafísica é, desde Aristóteles, aquilo que ultrapassa a física, apesar de estar relacionada à mesma, em função da necessidade de se fazer tal ultrapassagem. Por isso, em sua referência à física, a metafísica vê o mundo físico, gnosiologicamente, "objeto primeiro do conhecimento sensível e, portanto, mundo do 'sensível' (tòaisthetón), 
o que é conhecido como situado para além do sensível apresenta-se como puramente 'inteligível' (tonoetón). A metafísica é, pois, conhecimento do puramente inteligível" (LIMA VAZ, 2002, p. 274).

Não obstante a sua característica de ser conhecimento do inteligível, a metafísica há de ser considerada em seu caráter histórico, inclusive quando afetada pelo substrato filosófico da modernidade, marcadamente antropocêntrico e cientificista, em que atinge paradoxalmente o seu ápice e a sua crise. O ápice se deve à sua presença intrínseca na própria ciência moderna, que se apresentou messianicamente para ordenar e progredir a humanidade. A sua crise se deve ao próprio limite do messianismo científico, que não prevê outros elementos da cultura e a própria necessidade de ultrapassar o campo epistemológico, mediante a perspectiva da ética (GILBERT, 2008, p. 189-202). Neste sentido, tem razão Vattimo ao afirmar que Nietzsche é o iniciador da pós-modernidade, enquanto redimensionamento e entrada no paradoxo de continuidade e descontinuidade da modernidade.

Em função de que a metafísica se apresentou historicamente nos conceitos teológicos que forjaram valores da cultura ocidental e na própria ciência moderna, caracterizando-se como metafísica objetivista, a crítica nietzscheniana aparece como crítica metafísica do último dos metafísicos, cujo legado fundamental foi o de trazer o desafio de rememorar o ser. Neste sentido, o programa heideggeriano de superação da metafísica não se apresenta como fim da metafísica em stricto sensu, mas em seu redimensionamento na forma de ontologia hermenêutica. Para alcançar esse âmbito de ontologia é preciso considerar o caráter fenomenológico da metafísica (GILBERT, 2008, p. 190), cuja movimentação possibilita descrever as essências que aparecem à consciência, com atenção à objetidade, distinta da objetividade, e que possibilita colher aquilo que é a realidade. Disso resulta que a fenomenologia considera os eventos em sua singularidade e em sua visibilidade originária, desde que a realidade seja "capaz de aparecer, de surgir em aparências luminosas, a partir de sua interioridade própria” (GILBERT, 2008 p. 205).

Essa consideração possibilita identificar fenomenologia com ontologia, em perspectiva hermenêutica, de modo a salientar a fenomenologia como uma nova ciência primeira. Então, se a fenomenologia assume esse pleito, a metafísica fenomenológica não surge da obscuridade ou da maravilha do cosmos, mas da liberdade de outrem, de quem fala interpelativamente 
conosco, de quem está imbuído de mistério e de imprevisibilidade. Por isso, não se pode pensar os fenômenos, sejam científicos, religiosos, sociais, culturais, sem a ética que neles subjaz, permeia e transversa em toda a sua realidade. Justifica-se a ética em função de que se busca viver com razões denotativas da presença da outridade na vida humana. O outro é presença da diferença, da interpelação relacional, de um rosto propriamente diferente e diverso (LEVINAS, 1993), é aquele que possibilita suscitar a pergunta: como devemos e podemos viver? Disso resulta afirmar que a ética está na origem mesma da epistemologia da metafísica, sobretudo para discernir os modos universais de aparecimento e de rememoração do ser.

A posição niilista vattimiana de refutação da metafísica não pode ser compreendida em stricto sensu, mas tão somente naquilo que o autor denomina de objetivismo, dogmatismo, moralismo e legalismo. A metafísica é a própria tradição do pensamento ocidental, marcada por sua historicidade denotativa de substratos histórico-filosóficos e passíveis de reconfiguração. Neste sentido, a própria ontologia, que parece assumir o lugar da metafísica, retomando a metafísica na contemporaneidade (OLIVEIRA, 2014, p. 5-10), possui a tarefa de tornar a verdade revelada nas expressões de verdade, através de um processo que rememore o ser e incida como ética, que já está na origem da epistemologia conceitual própria da metafísica. O éthos da ética exige outridade, cuja universalização está na referência singular do próprio outro, colocada na perspectiva de vida realizada.

Diante do exposto, a própria a crítica aos fundamentos últimos necessita ser apurada cuidadosamente. Quando Heidegger (1976b) evoca o Grund - fundamento - , fá-lo trazendo à tona o Abgrund - sem fundamento ou desfundamento — , que possibilita pensar no abismo, não no sentido de ruína, mas no sentido de mais fundo ou profundo. Quando se considera a verdade como aletheia, a expressão de verdade está sempre aberta para a revelação da verdade em novas expressões, de modo a manifestar um processo de desconstrução e reconstrução epistemológico, sempre a considerar a vitalidade da tradição, que propicia a formulação de novas tradições. Disso resulta que a ética cristã não surgirá em cada época histórica sem a tradição da caridade, da esperança escatológica, da justiça divina, da comunhão dialógica, que é própria da formulação histórica da fé cristã. 
Ao considerar a própria elaboração heideggeriana acerca do Grund, torna-se necessário compreender que há três sentidos do fundar que leva ao fundamento: instituir, alicerçar e fundamentar. Fixemo-nos no fundar como instituir (PAIVA, 2015). Trata-se de fundar projeto no mundo e de mundo na temporalidade do próprio ser quando se lança no mundo. A fundação remete à instituição, imbuída de um tempo que se assenta e que requer ultrapassagem, porque o ser no mundo realiza a transcendência de forma ekstática-horizontal, propiciando que aquilo que é instituído pode ser desinstituído como maneira mesma de instituir. Em outras palavras, um cristianismo não religioso, que não é institucional e que funda uma ética cristã não religiosa, não é isento de instituição.

A institucionalização da ética cristã não religiosa se situa na própria hermenêutica niilista que remete ao sujeito a capacidade de elaborar elementos éticos para fundar o comunitarismo e levar a cabo a liberdade que é própria do cristianismo, em relação às questões diversas de sexualidade, origem e fim da vida e outras já elencadas acima. À vista disso, é importante remeter a Agostinho, em sua obra $A$ verdadeira religião, pela qual o cristianismo é considerado verdadeira religião não em função de suas estruturas organizacionais, mas em função de que o movimento da revelação de Deus interpela o homem a viver o cristianismo, em sua vera filosofia - pela qual se busca a beata vita - possessão de Deus através da via interior (GONÇALVES, 2016) —, realizando a caridade, sendo humilde e sempre fiel a Deus. Neste sentido, o cristianismo é uma religião da vivência do ser cristão, cujo ensinamento remete à ética fundada neste mesmo ser cristão situado e relacionado ao mundo. Por isso, o próprio cristianismo católico evoca a caridade como selo do próprio Deus - Deus caritas est (BENTO XVI, 2005) —, a misericórdia como intrínseca ao próprio Deus (FRANCISCO, 2016b), cabendo à Igreja encontrar formas reais para praticar a caridade e a misericórdia. Exemplo disso pode ser a exortação apostólica Amoris Laetitia, escrita pelo Papa Francisco (2016), em que, em vez de condenar pessoas divorciadas e em nova convivência conjugal e familiar, busca-se mostrar caminhos de acolhimento e cuidado misericordioso. Nesta mesma perspectiva,situa-sea ética social que, fundamentada em um grande patrimônio de ensino e doutrina social, condena a primazia do capital sobre o trabalho, uma economia centrada no mercado que depreda o planeta e aponta 
para uma sociedade que coloca o trabalho acima do capital, que tem uma cultura mundial da solidariedade e que se constitui em uma civilização do amor, da justiça e da paz (FRANCISCO, 2013). É importante ainda recordar que o cristianismo católico tem a consciência humana como santuário do homem e, por conseguinte, inviolável, mediante a qual o homem exerce a liberdade e o discernimento para o bom agir moral e para a efetividade da ética cristã (VALADIER, 2010).

Esses exemplos mostram que, ao se institucionalizar, o cristianismo não perde a sua capacidade de transcendência de seu próprio caráter institucional, cuja ética ultrapassa expressões conceituais para alcançar e realizar a verdade mesma do cristianismo, que está no evangelho, a ser apropriado e interpretado, de modo a tornar-se verdadeira boa notícia em cada época histórica. Desta maneira, a ética cristã há de se apresentar ética do amor e do amor em movimento, que é a caridade.

\section{Considerações finais}

Ao final deste artigo urge retomar o objetivo, a estrutura e seus pontos fundamentais. Objetivou-se analisar a relação entre ética e religião na proposta vattimiana do cristianismo não religioso, do qual decorre analogamente uma ética cristã não religiosa. Para atingir este objetivo, suscitou-se o status quaestionis intrínseco à própria pertinência e relevância de Gianni Vattimo, em uma visão filosófica da relação entre ética e religião, apresentando a proposta de um cristianismo não religioso em suas vertentes fundamentais e a ética dele decorrente, para então considerar dois pontos para debate, a metafísica e a institucionalização da ética cristã.

A proposta vattimiana de uma ética cristã não religiosa se fundamenta em uma ontologia fraca e em um pensamento débil, característicos da filosofia pós-moderna, em que se findaram as metanarrativas e se articularam a sentença nietzscheniana da morte de Deus e o projeto heideggeriano de superação da metafísica. Disso resulta, que a pós-modernidade está relacionada à flexibilidade, à transversalidade, à nomadologia do próprio pensamento e que uma hermenêutica niilista entra em ação para movimentar tal realidade. 
Ao aplicar essa ontologia hermenêutica niilista ao cristianismo, Vattimo compreende que se faz necessário pôr fim a um cristianismo que prega a verdade de modo absolutista, mediante suas prescrições dogmáticas, morais, jurídicas e disciplinares. Entende que o cristianismo é uma religião da encarnação do Verbo de Deus e, portanto, é uma religião que se situa no mundo e se relaciona com ele. Por ser religião da encarnação, há de seguir o próprio Verbo encarnado, cuja presença histórica é de manifestação e realização efetiva da caridade. Por ser religião da caridade e transfigurada, o cristianismo ultrapassa a instituição religiosa, marcadamente moralista, dogmatista e legalista, para ser um cristianismo não religioso imbuído de uma ética proveniente da fusão de horizontes e do diálogo, que prima pela liberdade do homem, expressão da própria religião cristã, uma vez que o seu evangelho é da liberdade e da caridade.

A proposta vattimiana suscita diversos pontos para debate, mas dois foram destacados neste artigo: a metafísica e a institucionalização da ética cristã. O projeto de superação da metafísica há de considerar a metafísica na própria tradição do pensamento ocidental, cuja tarefa de conhecer a inteligibilidade passou por mudanças de configuração, propiciando a emergência de um rosto ontológico-hermenêutico, fenomenológico, filosófico da diferença e que tem a ética como nova forma de sua constituição na contemporaneidade. Ora, se a ética é o novo nome da metafísica, então haverá de se ter atenção à presença do outro, com sua identidade alterativa e seu rosto que lhe constitui como diferente de mim. Ao ser o outro interpelativo à relação entre as diferenças, então a marca ética é a própria prática da caridade que leva à edificação de uma civilização com as marcas da justiça, da cultura solidária, das relações interpessoais fraternas e da paz entre os povos. Eis aqui a ética cristã, cuja veracidade paradoxalmente se situa e transcende a instituição religiosa cristã, propiciando a emergência do cristianismo como religião verdadeira, porque pratica a caridade que serve à verdade da revelação, cuja historicidade salvífica se situa na história da humanidade.

Portanto, a sustentação da ética cristã não está em pertencer ou não ao um cristianismo não religioso ou a um cristianismo institucional, mas em ser cristã mediante a efetividade da caridade, que é o amor em movimento na relação entre o eu e o outro, de modo a realçar a diferença na unidade das pessoas e dos povos, a unidade na diferença que marca cada pessoa e a cada povo. 


\section{Referências}

ALMEIDA, R. M. Deus está morto. A religião na perspectiva de Nietzsche. In: GONÇALVES, P. S. L. (org.). Um olhar filosófico sobre a religião. Aparecida: Ideias \& Letras, 2012. p. 51-76.

BARTH, K. A Palavra de Deus e a Palavra do Homem. São Paulo: Novo Século, 2004. BENTO XVI. Carta encíclica Deus caritas est. Vaticano: LibreriaEditriceVaticano, 2005. BONHOEFFER, D. Etica. Milano: Bompiani, 1969.

BULTMANN, R. Crer e Compreender. São Leopoldo: Sinodal, 2001

DE LUBAC, H. L'Ecritura dans La Tradition. Paris: Aubier, 1966.

DE LUBAC, H. Il drama dell'umanesimo ateo. Brescia: Morcelliana, 1978.

DERRIDA, J.; VATTIMO, G. (orgs.). A Religião: o Seminário de Capri. São Paulo: Estação Liberdade, 2000.

FRANCISCO. Carta encíclica Evangelii Gaudium. Vaticano: Libreria Editrice Vaticano, 2013.

FRANCISCO. Exortação Apostólica Amoris Laetitia. Vaticano: Libreria Editrice Vaticano, 2016a.

FRANCISCO; TORNIELLI, A. O nome de Deus é misericórdia. São Paulo: Planeta, 2016b.

GADAMER, H. G. Verdade e Método (I). Traços fundamentais de uma hermenêutica filosófica. Petrópolis - Bragança Paulista: Vozes - São Francisco, 2003.

GILBERT, P. Os caminhos da metafísica: da epistemologia à ética: ida-e-volta. Síntese - Rev. de Filosofia, Belo Horizonte, v. 35, n. 112, p. 189-210, 2008.

GIRARD, R. A Violência e o Sagrado. São Paulo: Paz e Terra/Unesp, 1990.

GIRARD, R. Não só interpretações, há também os fatos. In: GIRARD, R.; VATTIMO, G. Cristianismo e Relativismo. Verdade ou fé frágil? Aparecida: Santuário, 2013. p. 95-119. 
GIRARD, R. O bode expiatório. São Paulo: Paulus, 2004.

GONÇALVES, P. S. L. Ontologia Hermenêutica e Teologia. Aparecida: Santuário, 2011.

GONÇALVES, P. S. L. A religião à luz da fenomenologia hermenêutica heideggeriana. Horizonte, Belo Horizonte, v. 10, n. 26, p. 566-583, abr./jun. 2012.

GONÇALVES, P. S. L. A religião nas tensões e inquietações da vida: Análise Fenomenológica da experiência religiosa de Santo Agostinho. Revista Pistis \& Práxis, Teol. Pastor., Curitiba, v. 8, n. 2, p. 279-305, maio/ago. 2016.

HABERMAS, J. Entre Naturalismo e Religião. Estudos filosóficos. Rio de Janeiro: Tempo Brasileiro, 2007.

HEIDEGGER, M. Phänomenologie des Religösen Lebens. Gesamtausgabe 60. Frankfurt am Main: Vittorio Klostermann, 1995.

HEIDEGGER, M. Brief über den Humanismus. Wegmarken. Gesamtausgabe 9. Frankfurt am Main: Vittorio Klostermann, 1976a. p. 313-364.

HEIDEGGER, M. VomWesen des Grundes. Wegmarken. Gesamtausgabe 9. Frankfurt am Main: Vittorio Klostermann, 1976b. p. 313-364.

LEVINAS, E. Humanismo do outro homem. Petrópolis: Vozes, 1993.

LIMA VAZ, H. C. Escritos de Filosofia (VII). Raízes da modernidade. São Paulo: Loyola, 2002.

LYOTARD, J. F. O Pós-Moderno. Rio de Janeiro: José Olympio Editora, 1993.

OLIVEIRA, M. A. Pós-modernidade. Abordagem filosófica. In: GONÇALVES, P. S. L.; TRASFERETTI, J. Teologia na Pós-modernidade. Abordagens epistemológica, sistemática e teórico-prática.São Paulo: Paulinas, 2003. p. 21-52.

OLIVEIRA, M. A. A Ontologia em debate no pensamento contemporâneo. São Paulo: Paulus, 2014.

PAIVA, M. A. Da veritas a caritas: a religião depois da religião. Horizonte, Belo Horizonte, vol. 13, n. 37, p. 406-427, jan/Mar. 2015.

PEREZ, L. F. Acreditar em acreditar com Gianni Vattimo. Numen. Revista de Estudos e Pesquisa da Religião, Juiz de Fora, v. 15, n. 1, p. 187-215, jan./jun. 2012. 
PIXLEY, J. Exige o Deus verdadeiro sacrifícios cruentos? In: ASSMANN, H. (org.). René Girard com teólogos da libertação: um diálogo sobre ídolos e sacrifícios. Petrópolis: Vozes; Piracicaba: Unimep, 1991. p. 189-220.

ROTTERDAN, S.; SENRA, F. O cristianismo não religioso de Gianni Vattimo: considerações para o senso religioso contemporâneo. Religare, João Pessoa, v. 12, n. 1, p. 96-127, jun. 2015.

VALADIER, P. A condição cristã. São Paulo: Loyola, 2010.

VATTIMO, G. Credere di Credere: è possibile essere cristiani nonostante La Chiesa? Milano: Garzanti, 1998.

VATTIMO, G. O fim da modernidade. Niilismo e hermenêutica na cultura pós-moderna. São Paulo: Martins Fontes, 2002.

VATTIMO, G. Depois da Cristandade. Por um cristianismo não religioso. Rio de Janeiro; São Paulo: Record, 2004.

VATTIMO, G. Adeus à Verdade. Petrópolis: Vozes, 2016.

VON HERMANN, F. W. La Metafisica nelpensierodi Heidegger. Roma: Urbaniana University Press, 2004.

ZABALA, S. (org.). Il futuro della Religione. Milano: Garzanti, 2005.

Recebido: 18/05/2018

Received: 05/18/2018

Aprovado: 01/08/2018 Approved: 08/01/2018 